Article

\title{
Research on the Sustainable Heterogeneous Catalyst Development for Photocatalytic Treatment of Phenol
}

\author{
Zan $\mathrm{Li}^{1, *(\mathbb{D})}$, Hongkun Zhang ${ }^{1}$ and Wenrui Jiang ${ }^{2, *}$ \\ 1 School of Food Engineering, Harbin University, Harbin 150086, China; zhanghongkun2000@163.com \\ 2 School of Mechatronics Engineering, Harbin Institute of Technology, Harbin 150001, China \\ * Correspondence: lizan80@126.com (Z.L.); davisjwr@163.com (W.J.); Tel.: +86-132-6368-9968 (Z.L.); \\ +86-186-4623-6035 (W.J.)
}

Citation: Li, Z.; Zhang, H.; Jiang, W.

Research on the Sustainable

Heterogeneous Catalyst

Development for Photocatalytic

Treatment of Phenol. Sustainability

2021, 13, 4670. https://doi.org/

$10.3390 /$ su13094670

Academic Editor: Francisco

Pedrero Salcedo

Received: 1 March 2021

Accepted: 20 April 2021

Published: 22 April 2021

Publisher's Note: MDPI stays neutral with regard to jurisdictional claims in published maps and institutional affiliations.

\begin{abstract}
A large amount of wastewater from various and discharged sources that are not treated in any way could affect properties of both land and water, causing severe problems for the environment. Advanced oxidation processes seem to be a feasible option to address effluent treatment with regard to salvation of the environment. In this work, a $\mathrm{CdO} / \mathrm{ZnO} / \mathrm{Yb}_{2} \mathrm{O}_{3}$ composite composed of trimetallic semiconductors was synthesized through a simple one-pot hydrophile approach at low temperatures and then was employed as a photocatalyst. The degradation of phenol, a common organic persistent pollutant in industrial wastewater, was efficiently catalyzed in the presence of simulated sunlight. It was demonstrated that the synthesized $\mathrm{CdO} / \mathrm{ZnO} / \mathrm{Yb}_{2} \mathrm{O}_{3}$ photocatalyst was significantly active after $15 \mathrm{~min}$ of reaction and facilitated the effective degradation of the phenol. The $\mathrm{CdO} / \mathrm{ZnO} / \mathrm{Yb}_{2} \mathrm{O}_{3}$ photocatalyst achieved $71.5 \%$ and $97.81 \%$ degradation of the phenol without and with the existence of $\mathrm{H}_{2} \mathrm{O}_{2}$, correspondingly. The results show that the synthesized composite possesses high oxygen reduction capability and is available for rapid and potent photodegradation of the organic persistent pollutants such as phenol, with minimal damage to the environment.
\end{abstract}

Keywords: $\mathrm{CdO} / \mathrm{ZnO} / \mathrm{Yb}_{2} \mathrm{O}_{3}$; nanosheets; phenol; photocatalysis

\section{Introduction}

Contamination of aquatic resources has been recognized among the main concerns of developing and other developed nations. Large amounts of biological contaminants identified in aquatic bodies (drinkable water processing factories) usually come from distinct segments of industry (food, textile, oil and gas, printing, and medical industries). In particular, it is the textile industry that is one of the most polluting sectors for water bodies, because it uses large amounts of water, consumes high quantities of synthetic dyes, and produces a great deal of organic-rich wastewater. In addition to this, the textile industry is severely colored by dyes that do not adhere to the tissue's fabric in the processing [1-3].

Different approaches to water treatment are deployed to alleviate disposition of industrial polluted wastewater and reduce the influence of organic persistent pollutants from water to the environment to a minimum. These can be mentioned among others as biological treatment, which requires extended periods of time to bring the wastewater up to specification, filtration processes with the utilization of membranes [4], electrochemical methods [5], adsorption procedures [6], and advanced oxidation processes (AOP) [7]. Specifically, there has been much interest in the heterogeneous photocatalytic process as an advanced oxidation process due to its greater speed and effectiveness compared to other processes in the purification process.

In the photocatalytic process, the semiconductor material gets exposed to a light resource that has energies equal to or larger than their strip gaps. The radiation therefore fosters the stimulation of electrons that facilitate the generation of hydroxyl radicals $(\cdot \mathrm{OH})$ and other intervening species such as $\mathrm{O}_{2}^{--}$and $\mathrm{HO}_{2}^{\bullet}$ that have high oxidation capacity and can function to degrade organic contaminants of concern with even lower levels 
$(<100 \mathrm{ppm})[8,9]$. Wide-bandgap semiconductor oxides, comprising $\mathrm{TiO}_{2}, \mathrm{SnO}_{2}, \mathrm{ZnO}$, and $\mathrm{WO}_{3}[8-14]$, and metal salts (CdS and PbS) $[15,16]$ have been utilized in light-mediated photosensitizers for the oxygenation and reduction of organic molecules. Nevertheless, there are certain practical inconveniences associated with the implementation of high concentrations of such elements to rapidly mineralize chemical species of environmental concern, in addition to causing detriment to humans and aquatic ecosystems, given their temporary stability. Altogether, these prevent a majority of photocatalysts from being cemented as alternatives towards environmental solutions [17].

Accordingly, transitional metal oxides represent highly prospective candidates for use in photo-oxidation procedures, in particular, because of their redox characteristics and the fact that they are relatively more friendly to the environment than other metal systems. So far, there are various kinds of metal oxides that are used as electron mediators towards photocatalysts, including $\mathrm{TiO}_{2}, \mathrm{SnO}_{2}, \mathrm{WO}_{3}, \mathrm{In}_{2} \mathrm{O}_{3}, \mathrm{Fe}_{2} \mathrm{O}_{3}$, and $\mathrm{ZnO}$ [14]. In addition, there are bimetallic nanomaterials, which include $\mathrm{In}_{2} \mathrm{O}_{3} / \mathrm{ZnO}$ nanocomposites [18]. $\mathrm{CuO} / \mathrm{SnO}_{2}$ nanoparticles [19], $\mathrm{Ga}_{2} \mathrm{O}_{3} / \mathrm{In}_{2} \mathrm{O}_{3}$ nanocomposites [20], and $\mathrm{SnO}_{2} / \mathrm{ZnO}$ nanostructures [21], are already studied as competent and effective photocatalysts endowed with n-type wide band gaps and resistivities of $10^{-4}$ to $10^{12} \Omega \mathrm{cm}$, and $\mathrm{ZnO}$ has been regarded as a critical material for photocatalysts.

Electron/hole recombination restricts photocatalysis and hence must be prevented. As an additional trap for photogenerated charge generation, the metal cation avoids or decreases the electron/hole reorganization under any circumstances. Semiconductor metal oxides with $\mathrm{ZnO}$ as a bimetallic oxide pair, for instance, $\mathrm{SnO}_{2}, \mathrm{~V}_{2} \mathrm{O}_{5}, \mathrm{WO}_{3}$, and $\mathrm{MoO}_{3}$ [22], were examined in order to enhance the photocatalytic properties of $\mathrm{ZnO}$ [23]. Additionally, combinations of trimetallic oxides, like $\mathrm{Zn}_{0} \cdot 4 / \mathrm{Co}_{0.6} / \mathrm{Al}_{2} \mathrm{O}_{4}, \mathrm{ZnO} / \mathrm{Al}_{2} \mathrm{O}_{3} / \mathrm{TiO}_{2}$, and $\mathrm{ZnO} / \mathrm{SnO}_{2} / \mathrm{TiO}_{2}$ were also realized and demonstrated good photocatalytic active properties [24,25].

The photocatalyst is the core of photocatalysis; thus, developing highly efficient and stable photocatalytic materials is one of the emphases of photocatalytic research. Cadmium sulfide has attracted much attention for its excellent visible light response, and the band structure of CdS semiconductor perfectly satisfies the thermodynamic requirements for many photocatalytic reactions $[26,27] . \mathrm{Yb}_{2} \mathrm{O}_{3}$ is a kind of semiconductor material with strong heat resistance and good stability. It is widely used in coatings, fuel, ceramics, energy materials, environmental protection, and environmental catalysis and so on $[28,29]$.

In this context, the objective of this study was to prepare sustainable substances on the basis of $\mathrm{CdO} / \mathrm{ZnO} / \mathrm{Yb}_{2} \mathrm{O}_{3}$ by means of a one-pot hydrothermal method and apply them to the photocatalytic degradation of phenols driven by heterogeneous visible lighting. Phenol, which is considered to be durable, organic pollutants, and regular target molecules in wastewater are extensively exposed to the agate-dyeing, animal-feeding, and textile industries. Furthermore, phenol serves as a water-accessible fluorogenic tracer for the manufacture of inkjet and laser printer cartridges [30]. Notably, there are no studies on the photocatalytic properties of visible light for $\mathrm{CdO} / \mathrm{ZnO} / \mathrm{Yb}_{2} \mathrm{O}_{3}$ hydrothermally synthesized for phenol or other organic dyes.

\section{Experiment}

\subsection{Materials and Methodology}

A chemical of analytical grade was purchased from Sigma-Aldrich USA for use with no extra purification. State-of-the-art and extremely reliable equipment, known as the Thermo Scientific Nicolet iS50 FTIR Spectrometer (Madison, WI, USA) and 300 UV/Vis spectrophotometer, was applied to document the UV/Vis and FTIR spectra of $\mathrm{CdO} / \mathrm{ZnO} / \mathrm{Yb}_{2} \mathrm{O}_{3}$ nanosheets (NSs). Analysis of $\mathrm{CdO} / \mathrm{ZnO} / \mathrm{Yb}_{2} \mathrm{O}_{3} \mathrm{NSs}$ was carried out as an XPS study with the aim of identifying binding energy $(\mathrm{eV})$ amongst $\mathrm{Cd}, \mathrm{Zn}, \mathrm{Yb}$, and $\mathrm{O}$, with a K- $\alpha 1$ spectrometer (Thermo Scientific, K- $\alpha 1$ 1066), using the excitation source of radiation (A1 $\mathrm{K} \alpha 1$, spot size of $\frac{1}{4} 300.0 \mathrm{~mm}$, flux energy of $\frac{1}{4} 200.0 \mathrm{eV}$, pressure of $\sim 10^{-8}$ Torr). Examination of the molecular alignment, elemental analysis, morphology, particle size, and other 
optical properties of $\mathrm{CdO} / \mathrm{ZnO} / \mathrm{Yb}_{2} \mathrm{O}_{3}$ NSs was conducted via a FESEM device (JEOL, JSM-7600F, Tokyo, Japan) installed with XEDS. XRD evaluations were carried out under environmental conditions for the purpose of analyzing the crystallinity of $\mathrm{CdO} / \mathrm{ZnO} / \mathrm{Yb}_{2} \mathrm{O}_{3}$ NSs. The surface areas of Brunauer-Emmett-Teller (BET) were acquired on an instrument of Micromeritics Tristar 3000 by means of a nitrogen physisorption isotherm at $77 \mathrm{~K}$ (adsorption-desorption branch).

\subsection{Synthesis of $\mathrm{CdO} / \mathrm{ZnO} / \mathrm{Yb}_{2} \mathrm{O}_{3} \mathrm{NSs}$}

$\mathrm{CdO} / \mathrm{ZnO} / \mathrm{Yb}_{2} \mathrm{O}_{3} \mathrm{NSs}$ were generated through a hydrothermal method with $0.1 \mathrm{M}$ of $\mathrm{CdCl}_{2}, \mathrm{ZnCl}_{2}, \mathrm{YbCl}_{3}$, and $\mathrm{NH}_{4} \mathrm{OH}$ as reaction precursors. The hydrothermal technique, which is a classic solid-state system, has been broadly implemented in making doped nanomaterials, and the resulting nanomaterials exhibit minor size and rational grain size smaller than the size of the phase formation. According to the method [31], a mixture of $\mathrm{CdCl}_{2}, \mathrm{YbCl}_{3}$, and $\mathrm{ZnCl}_{2}$ was solubilized with distilled water $(50.0 \mathrm{~mL})$ and stirred constantly in a tapered flask $(150.0 \mathrm{~mL})$. After adjusting a $\mathrm{pH}$ of 11 to the obtained solution through the addition of $\mathrm{NH}_{4} \mathrm{OH}$, it was subjected to a constant magnet stirring regime by putting the entire solution in an oven at $180.0^{\circ} \mathrm{C}$. Eventually, the resulting NSs attained were exposed to a muffle oven and calcined at $600{ }^{\circ} \mathrm{C}$ for about $4 \mathrm{~h}$. The calcined samples were then described by UV, FTIR, XPS, XRD, and FESEM.

$$
\begin{aligned}
\mathrm{NH}_{4} \mathrm{OH}(\mathrm{s}) & \rightarrow \mathrm{NH}_{4}(\mathrm{aq})^{+}+\mathrm{OH}(\mathrm{aq})^{-} \\
\mathrm{ZnCl}_{2} & \rightarrow \mathrm{Zn}(\mathrm{aq})^{2+}+2 \mathrm{Cl}(\mathrm{aq})^{-} \\
\mathrm{CdCl}_{2} & \rightarrow \mathrm{Cd}(\mathrm{aq})^{2+}+2 \mathrm{Cl}(\mathrm{aq})^{-} \\
\mathrm{YbCl}_{3} & \rightarrow \mathrm{Yb}(\mathrm{aq})^{3+}+3 \mathrm{Cl}(\mathrm{aq})^{-}
\end{aligned}
$$

$$
\begin{aligned}
\mathrm{NH}_{4}(\mathrm{aq})^{+}+7 \mathrm{OH}(\mathrm{aq})^{-}+\mathrm{Zn}(\mathrm{aq})^{2+}+ & \mathrm{Cd}(\mathrm{aq})^{2+}+\mathrm{Yb}(\mathrm{aq})^{3+}+\mathrm{Cl}(\mathrm{aq})^{-} \rightarrow \mathrm{Zn}(\mathrm{OH})_{2}(\mathrm{aq}) \downarrow+\mathrm{Cd}(\mathrm{OH})_{2}(\mathrm{aq}) \downarrow \\
+ & \mathrm{Yb}(\mathrm{OH})_{3}(\mathrm{aq}) \downarrow+\mathrm{NH}_{4} \mathrm{Cl}(\mathrm{aq}) \\
\mathrm{Zn}(\mathrm{OH})_{2}(\mathrm{aq}) \downarrow+\mathrm{Cd}(\mathrm{OH})_{2}(\mathrm{aq}) \downarrow & +2 \mathrm{Yb}(\mathrm{OH})_{3}(\mathrm{aq}) \downarrow \rightarrow \mathrm{CdO} / \mathrm{ZnO} / \mathrm{Yb}_{2} \mathrm{O}_{3}(\mathrm{~s}) \downarrow+5 \mathrm{H}_{2} \mathrm{O}(\mathrm{aq})
\end{aligned}
$$

From Equations (1)-(6) above, the progression of the reaction was found to be slow. The $\mathrm{pH}$ of the reaction medium acts as an important factor in producing the tertiary metallic oxide $\mathrm{CdO} / \mathrm{ZnO} / \mathrm{Yb}_{2} \mathrm{O}_{3} \mathrm{NSs}$. At a defined $\mathrm{pH}, \mathrm{ZnCl}_{2}$ is promptly hydrolyzed to generate zinc hydroxide in an alkaline solution (ammonium hydroxide) based on Equation (5). For this reason, $\mathrm{NH}_{4} \mathrm{OH}$ served to adjust the $\mathrm{pH}$ (alkaline phase) and the slow transport of hydroxyl ions $\left(\mathrm{OH}^{-}\right)$into the reaction mediator. On approaching a cut-off value for the concentration of $\mathrm{Zn}^{2+}$ and $\mathrm{OH}^{-}$ions, nuclei begin to form with a solution of $\mathrm{Zn}(\mathrm{OH})_{2}$. As the level of $\mathrm{Yb}^{3+}$ and $\mathrm{Cd}^{2+}$ ions gets higher (reaction (3-5)), soluble $\mathrm{Zn}(\mathrm{OH})_{2}$ crystals nucleate at a slower rate due to the lower energy of activation of $\mathrm{Zn}(\mathrm{OH})_{2}$ and the formation of heterogeneous nuclei with those of other oxides, typically $\mathrm{Cd}(\mathrm{OH})_{2}$, $\mathrm{Yb}(\mathrm{OH})_{3}$, or $\mathrm{Zn}(\mathrm{OH})_{2}$. Reaction regimes with high concentrations of $\mathrm{Yb}^{3+}$ and $\mathrm{Cd}^{2+}$ trigger some bigger $\mathrm{Cd}(\mathrm{OH})_{2} / \mathrm{Zn}(\mathrm{OH})_{2} / \mathrm{Yb}(\mathrm{OH})_{3}$ crystals to develop immiscible agglomerates featuring a lamellar formation as per reactions (5) and (6). The resulting crystals were then cleaned completely with acetone, ethyl alcohol, and aqueous one after another and kept dry at indoor temperatures. At last, they were calcined by putting the immiscible $\mathrm{Cd}(\mathrm{OH})_{2} / \mathrm{Zn}(\mathrm{OH})_{2} / \mathrm{Yb}(\mathrm{OH})_{3}$ nanocrystals into a stove (Barnstead Thermoelectric, 6000 furnace, US) at $600.0{ }^{\circ} \mathrm{C}$ for $4 \mathrm{~h}$. Based on the nanoparticle growth theory of the Ostwald-ripening approach, initially, the $\mathrm{CdO} / \mathrm{ZnO} / \mathrm{Yb}_{2} \mathrm{O}_{3} \mathrm{NSs}$ nuclei advance through self- and inter-agglomeration and subsequently recombine a second time to constitute $\mathrm{CdO} / \mathrm{ZnO} / \mathrm{Yb}_{2} \mathrm{O}_{3} \mathrm{NSs}$. The internal order of molecules in the nanocrystals corresponds to the other via Van der Waals forces. 


\subsection{Photocatalytic and Absorption Experiment}

Photocatalytic effectiveness of $\mathrm{CdO} / \mathrm{ZnO} / \mathrm{Yb}_{2} \mathrm{O}_{3}$ NSs on phenol solutions was assessed. The tests were carried out in a custom-made photoreactor, which incorporated a UV and visually illuminated light source positioned overhead. Irradiation of the samples was carried out with a PHILIPS cleo $90 \mathrm{~W}$ TL-D Actinic BL for various times at a maximal emission wavelength of $365 \mathrm{~nm}$. The combined UV radiation on cells at wavelengths in the 290-400 $\mathrm{nm}$ range was $90 \pm 2 \mathrm{Wm}^{-2}$. Once irradiated, specimens were passed over a $0.45 \mu \mathrm{m}$ filter and then analyzed using appropriate analytical technologies.

Throughout the reaction, a distance of $10 \mathrm{~cm}$ was kept between the lamp and the solution. To conduct the experiments, $10.0 \mathrm{mg}$ of oxide $\left(667 \mathrm{mg} \cdot \mathrm{L}^{-1}\right)$ was scattered in petri plates that held $15.0 \mathrm{~mL}$ of a pre-prepared phenol stock solution with a concentration of $5.0 \mathrm{mg} \cdot \mathrm{L}^{-1}$ at $22{ }^{\circ} \mathrm{C}$. The suspension (solution and photocatalyst) was placed in darkness and stirred magnetically for $60 \mathrm{~min}$ to create an adsorption-desorption equilibrium.

All experiments were all undertaken at $\mathrm{pH} 7.0$ (the normal $\mathrm{pH}$ of a phenol concentration of $7.0 \mathrm{mg} \cdot \mathrm{L}^{-1}$ ) and were performed in triplicate. In the same circumstances, photolysis tests were carried out without the photocatalyst, as opposed to adsorption tests, which were conducted in darkness, by applying the identical method outlined in an earlier report [32].

It was necessary to include $\mathrm{H}_{2} \mathrm{O}_{2}\left(30 \mathrm{mg} \cdot \mathrm{L}^{-1}\right)$ and isopropyl alcohol in the reaction container for examining the effect of hydroxyl radicals $\left(\mathrm{OH}^{*}\right)$ on photocatalysis. According to literature reports, it was found that $0.5 \mathrm{~mL}$ of $\mathrm{H}_{2} \mathrm{O}_{2}$ suffices to further improve the forming of $\mathrm{OH}^{-}$and increase the material's catalytic efficiency.

Consequently, it was determined that in order to assess the photolysis, adsorption capability, and photocatalytic effectiveness of the oxide both with or without the presence of $\mathrm{H}_{2} \mathrm{O}_{2}$, an equal amount of solution was gathered from a Petri dish for 15 min after the reaction, followed by centrifugation and filtration. Subsequently, with the use of a Shimadzu UV-1800 spectrophotometer, it was possible to analyze the resulting solution based on UV-Vis absorption spectroscopy over a wavelength scan ranging from 240 to $800 \mathrm{~nm}$. As a result, the ultimate concentration of the solution could be derived through observing the largest absorption band of phenol at $271 \mathrm{~nm}$ following Equation (7), proposed by Rahman et al. [33] and Chantelle et al. [34]:

$$
\text { Degradation rate }(\%)=\left(\frac{C_{0}-C}{C_{0}}\right) \times 100
$$

in which $C_{0}$ represents the original concentration at $0 \mathrm{~min}$ and $C$ represents the changing concentration as time progresses.

\section{Results and Discussion}

\subsection{Photocatalytic Characteristics}

\subsubsection{Analysis of Optics and Structures}

One of the key features in evaluating the photocatalytic efficiency of $\mathrm{CdO} / \mathrm{ZnO} / \mathrm{Yb}_{2} \mathrm{O}_{3}$ NSs is their optical properties. The spectrum presents an intense, consistent, and extensive band at $307 \mathrm{~nm}$, which indicates the valence band electronic transition from lower to higher energy levels for the $\mathrm{CdO} / \mathrm{ZnO} / \mathrm{Yb}_{2} \mathrm{O}_{3}$. Figure $1 \mathrm{a}$ illustrates the data derived from the Tauc plot with the use of a UV-Vis spectrophotometer. The photon energy and absorption coefficient could be achieved with the Tauc model by means of a relation, as shown in Equation (8), in which the notations, $\alpha, h v, A, E g$, and $n$ denote the absorption coefficient, proportionality constant, photon energy, optical bandgap energy, and an integral number, correspondingly. The band-gap values are derived through additional plotting of Tauc curves to the energy axis (X-axis), as shown in the figure. The band gap of $\mathrm{CdO} / \mathrm{ZnO} / \mathrm{Yb}_{2} \mathrm{O}_{3}$ was $4.04 \mathrm{eV}$, which is higher than $\mathrm{ZnO}(3.30 \mathrm{eV})$. The $\mathrm{CdO} / \mathrm{ZnO} / \mathrm{Yb}_{2} \mathrm{O}_{3}$ ternary composite could induce more electronic species that are placed at certain higher Fermi sites compared to the single materials, thus expanding the energy band gap [27]. The newly prepared ternary composite with the higher band gap was able to absorb a higher 
portion of irradiated UV from the lamp than $\mathrm{ZnO}$, and thus, photocatalytic performances could be improved.

$$
(\alpha h v)=\mathrm{A}\left(h v-E_{g}\right)^{n}
$$
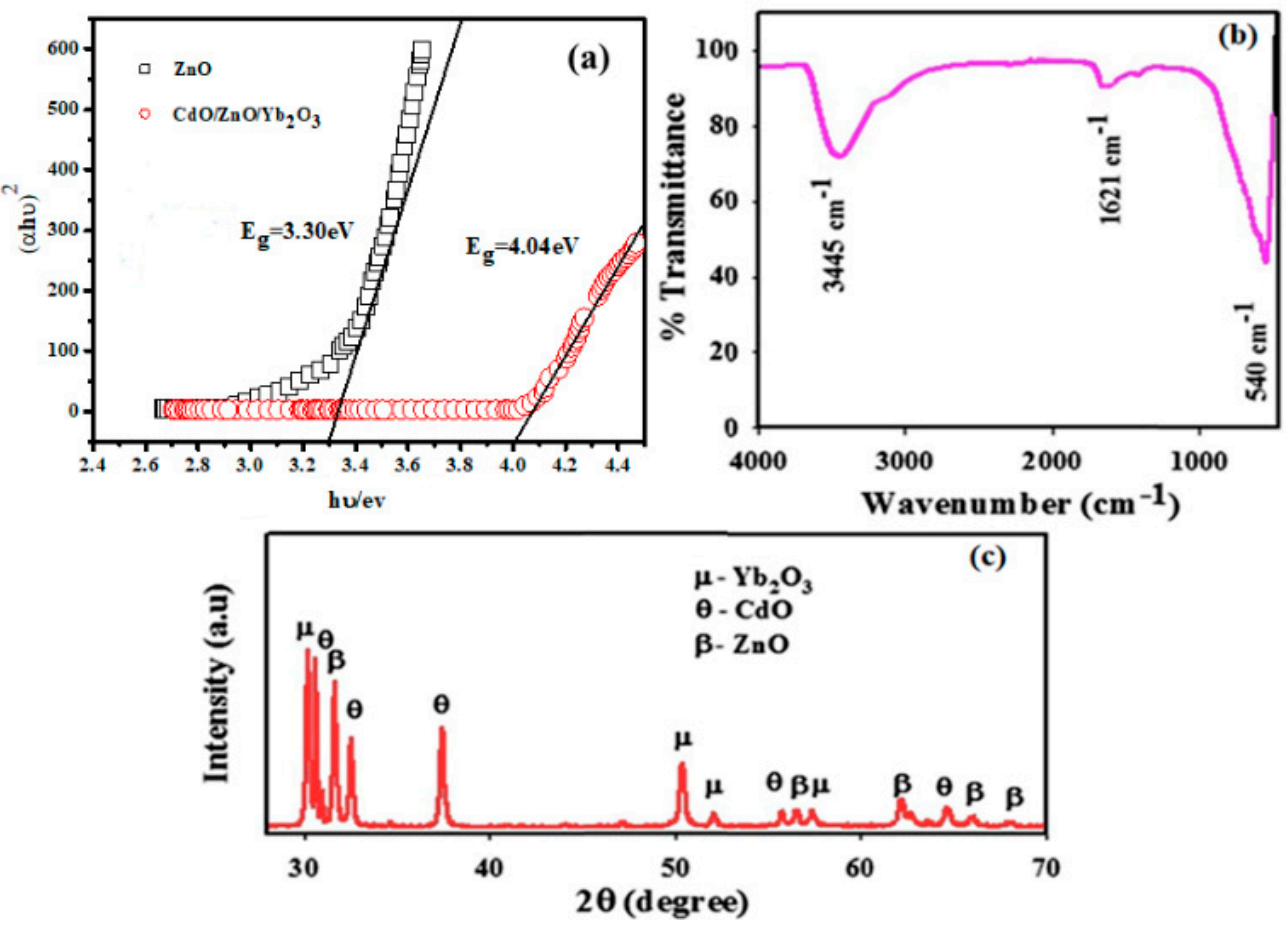

Figure 1. Optical and morphological assessment via (a) UV-vis DRS, (b) FTIR, and (c) XRD modes of $\mathrm{CdO} / \mathrm{ZnO} / \mathrm{Yb}_{2} \mathrm{O}_{3} \mathrm{NSs}$.

FTIR offers a modern tool for analysis, enabling the identification of the functional characteristics of atoms or molecules through their appropriate vibrances of the atoms and molecules. Accordingly, the NSs synthesized by $\mathrm{CdO} / \mathrm{ZnO} / \mathrm{Yb}_{2} \mathrm{O}_{3}$ were researched through FTIR analysis, which was carried out within the $450-4000 \mathrm{~cm}^{-1}$ region, as shown in Figure 1b. Based on the FTIR spectra, the primary peaks identified were found at 3445, 1621 , and $540 \mathrm{~cm}^{-1}$. The peaks at 3445 and $1621 \mathrm{~cm}^{-1}$ are, respectively, correlated with the standard $\mathrm{OH}$ stretched and $\mathrm{H}_{2} \mathrm{O}$ bent modes. At $540 \mathrm{~cm}^{-1}$, the peak is associated with $\mathrm{Cd}-\mathrm{O}$ or $\mathrm{Zn}-\mathrm{O}$ or $\mathrm{Yb}-\mathrm{O}$ stretching $[35,36]$, X-ray powder diffraction $(\mathrm{XRD})$ being considered among the standard techniques of analysis and extensively adopted to identify the phase of crystalline nanomaterials, which conveys information on the size of the single cell. To investigate the structural characteristics and crystalline phases of the synthesized $\mathrm{CdO} / \mathrm{ZnO} / \mathrm{Yb}_{2} \mathrm{O}_{3} \mathrm{NSs}$, the $\mathrm{XRD}$ method is applied using $\mathrm{Cu}-\mathrm{K} 1$ radiation $(=1.54178 \AA)$ at a $2^{\circ} \mathrm{min}^{-1}$ scan rate in the range of $10-80^{\circ}$. The XRD pattern observed demonstrated that the NSs possessed good crystalline properties and presented a mixed phase of $\mathrm{Cd}-\mathrm{O}, \mathrm{Zn}-\mathrm{O}$, and $\mathrm{Yb}_{2} \mathrm{O}_{3}$, as illustrated in Figure 1c. The pronounced diffraction reflexes with $\mathrm{ZnO}$ Index of $\beta$ were (100), (110), (103), (112), and (200), comparable to the hexagonal phases of $\mathrm{ZnO}$ bulk and $\mathrm{ZnO}$ [37].

The observations report showed significant resemblance to the JCPDS standard data card (JCPDS No. 36-1451), with several additional peaks for CdO index, as $\theta$ were (111), (200), (220), (311), and (222) respectively, which are in excellent agreement with the literature reports [38].

In addition to this, several other sharp peaks with a $\mathrm{Yb}_{2} \mathrm{O}_{3}$ index of $\mu$ were identified in the mode of XRD diffraction, respectively, denoted as (110), (101), (112), and (200), in full agreement with the literature reports $[39,40]$.

Furthermore, sharpness of the peaks indicates excellent crystallization of the product NSs. 


\subsubsection{Analysis of Morphology and Elements}

The morphological studies of the synthesized $\mathrm{CdO} / \mathrm{ZnO} / \mathrm{Yb}_{2} \mathrm{O}_{3} \mathrm{NSs}$ were probed by FESEM, resulting in representative low and high magnification FESEM images illustrated in Figure 2a,b. Typical TEM images of the sample are shown in Figure 2c. These images clearly demonstrate homogeneous and arranged $\mathrm{CdO} / \mathrm{ZnO} / \mathrm{Yb}_{2} \mathrm{O}_{3}$ nanoflakes [41]. Energydispersive $\mathrm{X}$-ray spectroscopy (EDS) probing of the $\mathrm{CdO} / \mathrm{ZnO} / \mathrm{Yb}_{2} \mathrm{O}_{3}$ NSs showed the presence of aligned $\mathrm{Cd}, \mathrm{Yb}, \mathrm{Zn}$, and $\mathrm{O}$ among the pure calcined-doped materials of the nanosheets and explicitly revealed the organization of the calcined-prepared materials with $\mathrm{Cd}, \mathrm{Zn}, \mathrm{Yb}$, and oxygen elements, as shown in Figure $2 \mathrm{~d}$. The contents of $\mathrm{Cd}, \mathrm{Yb}, \mathrm{Zn}$, and $\mathrm{O}$ are $4.67 \%, 9.24 \%, 61.22 \%$, and $24.87 \%$, respectively. The absence of any other peaks in the EDS indicates the $\mathrm{CdO} / \mathrm{ZnO} / \mathrm{Yb}_{2} \mathrm{O}_{3}$ NSs product is exclusively composed of $\mathrm{Cd}$, $\mathrm{Yb}, \mathrm{Zn}$, and $\mathrm{O}[34]$.

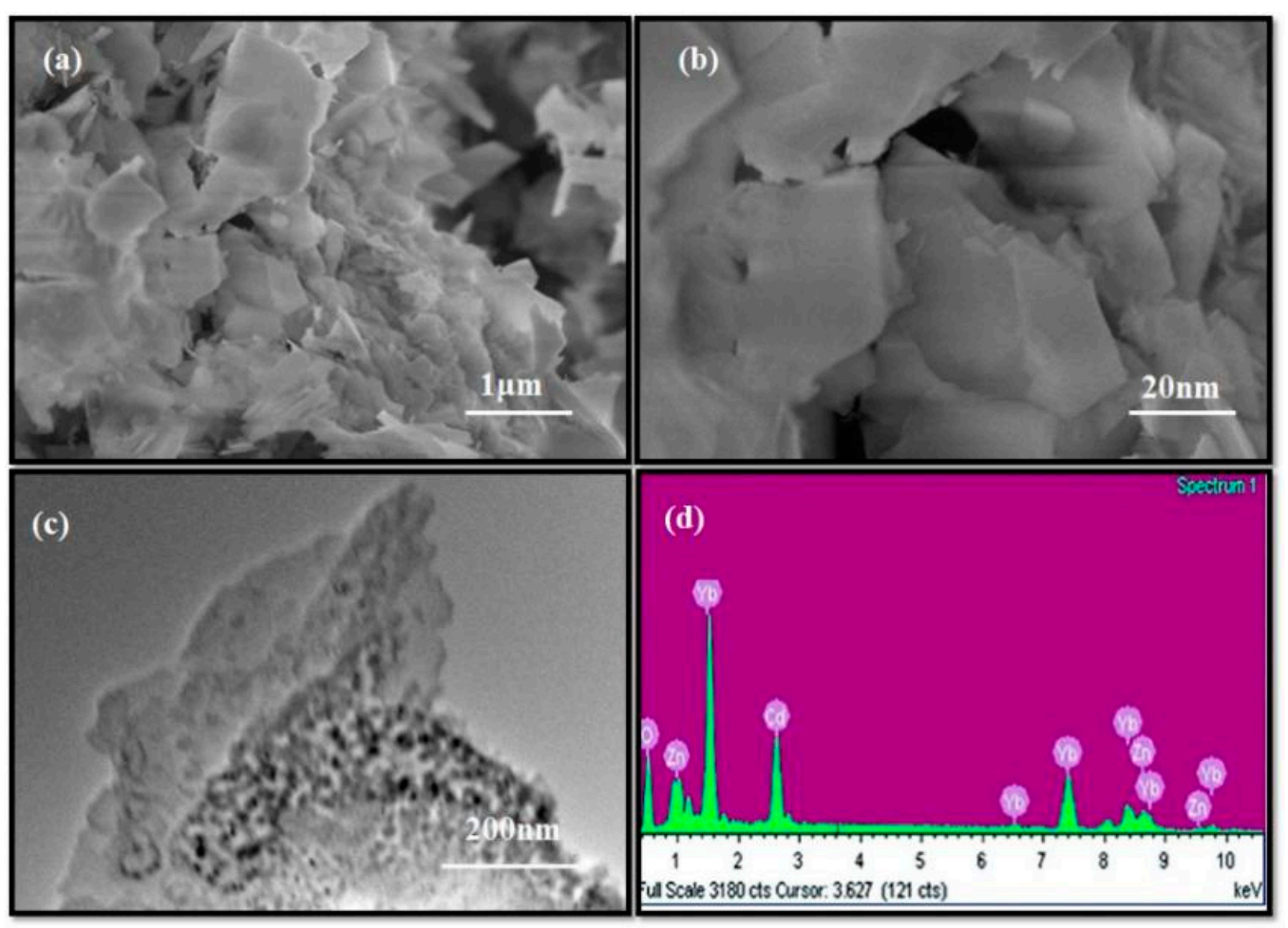

Figure 2. (a,b) FESEM analysis of low to high magnetic images, (c,d) TEM image and EDS of the $\mathrm{CdO} / \mathrm{ZnO} / \mathrm{Yb}_{2} \mathrm{O}_{3}$ NSs.

\subsubsection{Analysis of XPS}

In order to pre-prove the compositional configuration present in the prepared specimens $\mathrm{CdO} / \mathrm{ZnO} / \mathrm{Yb}_{2} \mathrm{O}_{3} \mathrm{NSs}$, XPS, a quantitative spectroscopy technology, was practiced for the NSs. The implications of XPS detection allow the chemical nature and kinetic energy of the elements present to be expected, which includes the amount of electrons present in the specimen at the time of X-ray beam irradiation [42]. Figure 3 shows high resolution XPS spectra of $\mathrm{Cd} 3 \mathrm{p}, \mathrm{O} 1 \mathrm{~s}, \mathrm{Yb} 4 \mathrm{~d}$, and $\mathrm{Zn} 2 \mathrm{p}$. With respect to the primary two same peaks of the $\mathrm{Cd} 3 \mathrm{~d}$ orbital, no significant variation is observed between the two peaks, which both are indicative of an equal $\mathrm{Cd}$ oxidation status. In Figure $3 c$, the binding energies are 406.08 and $414.08 \mathrm{eV}$ for $\mathrm{Cd} 3 \mathrm{~d}_{5 / 2}$ and $\mathrm{Cd} 3 \mathrm{~d}_{3 / 2}$, separately, which are eigenvalues of $\mathrm{Cd}^{2+}$ in $\mathrm{CdO}$. The $\mathrm{O} 1 \mathrm{~s}$, which is wide and asymmetric in Figure $3 \mathrm{~b}$, illustrates the existence of hyper-component oxygen species [43]. In Figure 3d, binding energies of 1023.08 and $1046.08 \mathrm{eV}$ were observed for the $\mathrm{Zn} 2 \mathrm{p}_{3 / 2}$ and $\mathrm{Zn} 2 \mathrm{p}_{1 / 2}$ peaks, corresponding to eigenvalues of $\mathrm{Zn}^{2+}$ oxidation in $\mathrm{ZnO}$ [44]. In addition, the apparent peak of the $\mathrm{Yb} 4 \mathrm{~d}$ spectrum from Figure $3 \mathrm{e}$ is orientated at $185.08 \mathrm{eV}$ and could be identified as $\mathrm{Yb} 4 \mathrm{~d}_{5 / 2}$, in considerable agreement with the $\mathrm{Yb} 4 \mathrm{~d}$ binding energy of $\mathrm{Yb}_{2} \mathrm{O}_{3}[45,46]$. 


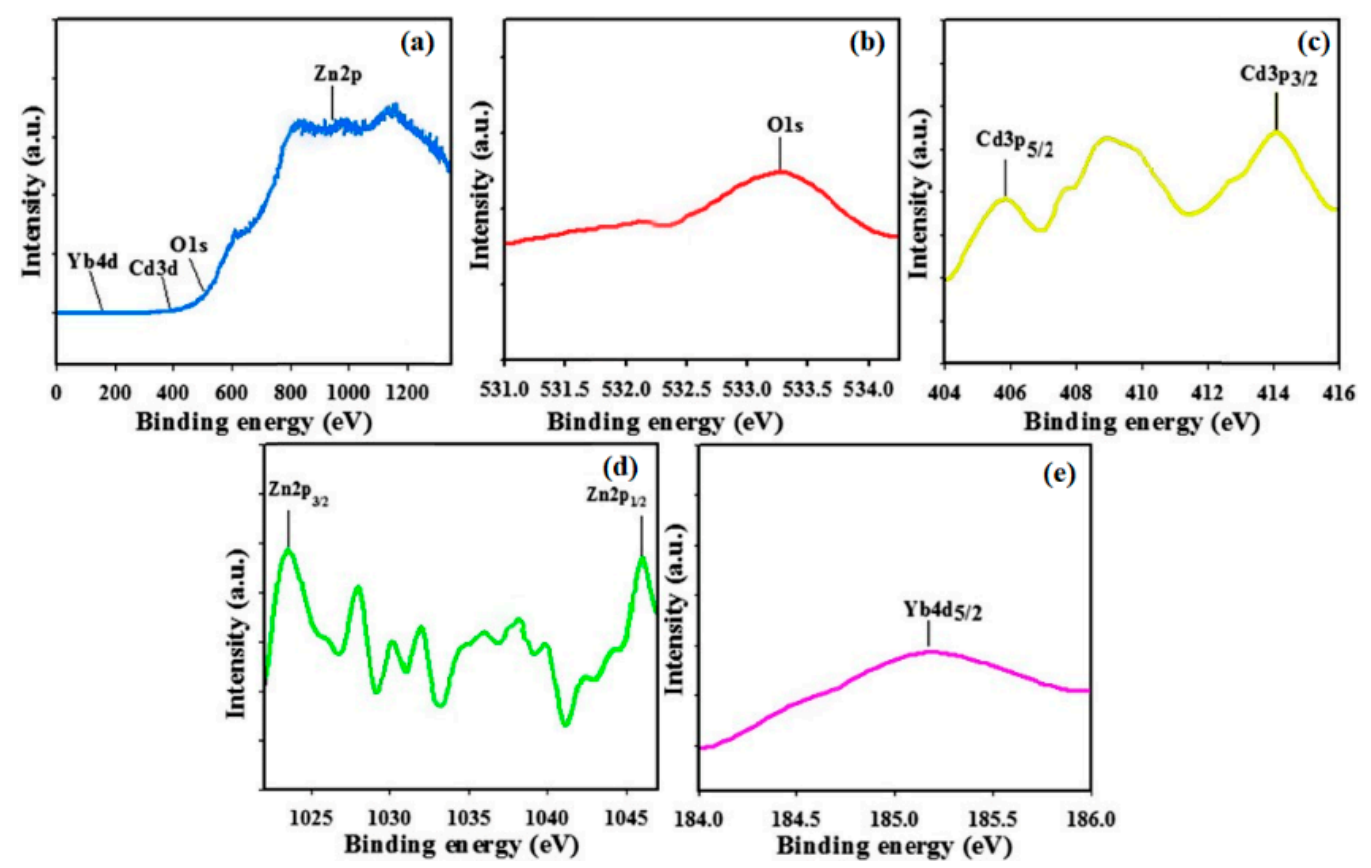

Figure 3. Binding energy analysis of $\mathrm{CdO} / \mathrm{ZnO} / \mathrm{Yb}_{2} \mathrm{O}_{3}$ NSs studied by XPS: (a) full spectrum, (b) O 1s, (c) spin orbit Cd 3p level, (d) spin orbit Zn 2p level, and (e) spin orbit $\mathrm{Yb} 4 \mathrm{~d}$ level.

\subsection{Photocatalytic Experiments}

\subsubsection{Photocatalytic Activation and Potential Mechanism}

In view of the photo-stability of phenol, it is necessary to apply a photocatalyst to facilitate the complete degradation. On this background, the photodegradation of phenol solutions (5 mg. $\mathrm{L}^{-1}$, $\mathrm{pH} 7$ ) by $\mathrm{CdO} / \mathrm{ZnO} / \mathrm{Yb}_{2} \mathrm{O}_{3} \mathrm{NSs}$ under UV-visible light for $15 \mathrm{~min}$ was carried out.

Two different mechanisms have been reported in the literature to characterize photocatalysis, i.e., a direct mechanism and an indirect mechanism. With respect to the direct mechanism, there is a transfer of electrons from the catalyst to the compound being oxidized, whereas in indirect photocatalysis the catalyst surface yields strong oxidants. Such oxidants have the ability to react uniformly with organic compounds to degrade them $[47,48]$. The adsorption on the catalyst is required for the indirect mechanism to take place. Therefore, the adsorption experiments were also carried out to better understand this point, as illustrated in Figure $4 \mathrm{a}$. It was noticed that when $\mathrm{CdO} / \mathrm{ZnO} / \mathrm{Yb}_{2} \mathrm{O}_{3} \mathrm{NS}$ s were employed, the adsorption of the phenol reached approximately $28.5 \%$. On the other side, the BET surface area of NSs were $19.7 \mathrm{~m}^{2} \cdot \mathrm{g}^{-1}$. The BET surface area of $\mathrm{ZnO}$ was $15.6 \mathrm{~m}^{2} \cdot \mathrm{g}^{-1}$. In particular, it is possible that the distinct adsorption behavior of the $\mathrm{CdO} / \mathrm{ZnO} / \mathrm{Yb}_{2} \mathrm{O}_{3}$ NSs could account for the existence of various sorts of flaws on the catalyst surface, as the high specific surface areas under observation for both types of materials appear to play a significant role in this procedure, while we can assume that indirect mechanisms may be the most significant manner in which phenol photodegradation takes place in the existence of such catalysts.

In order to quantify the reaction kinetics of phenol degradation in the experiment, we employed a pseudo-first order model for low concentrations.

$$
\ln \left(C_{t} / C_{0}\right)=-\mathrm{k} t
$$

$C_{0}$ and $C_{t}$ are concentrations in the aqueous solution by time $t=0$ and $t$ and $\mathrm{ka}$ is the pseudo-first order rate constant, derived from the equation $\ln \left(C_{t} / C_{0}\right)$ vs $t$ plotted in Figure $4 \mathrm{~b}$. The largest reaction rate constant was $0.02882 \mathrm{~min}^{-1}$ for $\mathrm{CdO} / \mathrm{ZnO} / \mathrm{Yb}_{2} \mathrm{O}_{3}$ under UV-vis light. In this respect, the degradation of phenol by $\mathrm{CdO} / \mathrm{ZnO} / \mathrm{Yb}_{2} \mathrm{O}_{3} \mathrm{NSs}$ attained $71.5 \%$ (Figure $4 \mathrm{~d}$ ). 
For the assessment of the photostability of phenol under UV-Vis exposure, a photolysis test (control reaction) was conducted without a photocatalyst. The UV-Vis spectra of the phenol solutions prior to and after photolysis are indicated in Figure 4c. There was no significant drop in the maximal absorption band of phenol after $15 \mathrm{~min}$ of radiation. The maximal absorption at $271 \mathrm{~nm}(\mathrm{E}=4.57 \mathrm{eV})$ features the chromophore that is in charge of the coloration of the dye. The low reduction of this band following photolysis is equivalent to a discoloration of around $4.66 \%$.
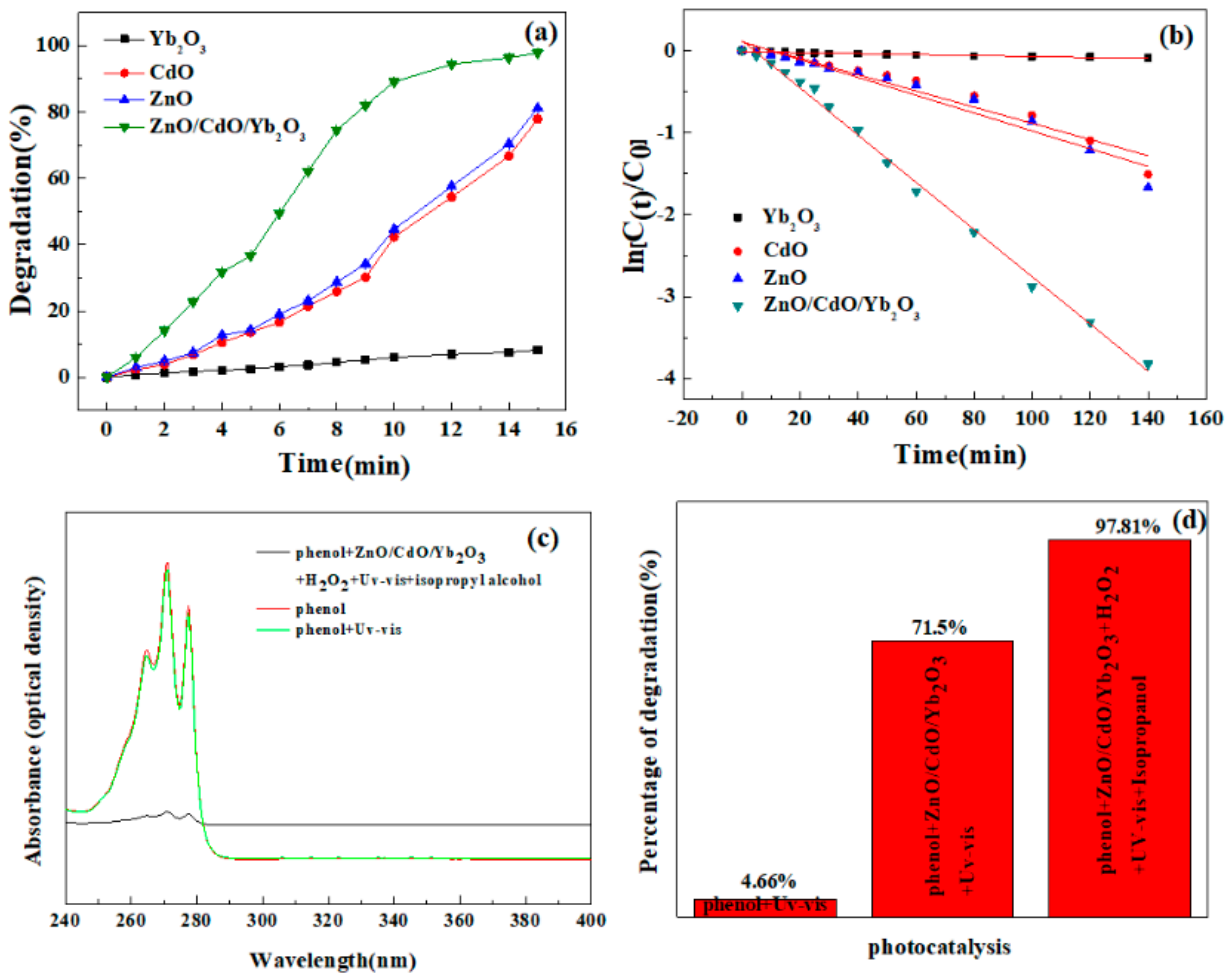

Figure 4. (a) Comparison of the photocatalytic properties of pure $\mathrm{ZnO}, \mathrm{CdO}, \mathrm{Yb}_{2} \mathrm{O}_{3}$, and $\mathrm{CdO} / \mathrm{ZnO} / \mathrm{Yb}_{2} \mathrm{O}_{3}$ samples. (b) The corresponding rate constant $\mathrm{k}$ for different photocatalysts. (c) UV-Vis absorption spectra of phenol, phenol under UV-Vis, and phenol with $\mathrm{CdO} / \mathrm{ZnO} / \mathrm{Yb}_{2} \mathrm{O}_{3} / \mathrm{H}_{2} \mathrm{O}_{2} /$ isopropanol under UV-Vis. (d) Degradation rate of the phenol solution with UV-Vis, catalysts/UV-Vis, and catalysts/UV-Vis $/ \mathrm{H}_{2} \mathrm{O}_{2} /$ isopropanol.

Diverse variables may influence the photocatalytic behavior of a material. The crystalline architecture and surface deficiencies, in combination with the particle size and surface area, for example, are essential factors influencing the photocatalysis that takes place as a result of the reaction between the phenol molecules and the catalyst [34]. It was noticed that the superior photocatalytic activities of $\mathrm{CdO} / \mathrm{ZnO} / \mathrm{Yb}_{2} \mathrm{O}_{3} \mathrm{NS}$ may be due to the structural flaws in the material itself or the existence of ionic deficiencies in the material. Consequently, high interaction between phenol and the surface of $\mathrm{CdO} / \mathrm{ZnO} / \mathrm{Yb}_{2} \mathrm{O}_{3}$ NSs arises, resulting in the enhanced adsorption capability of such oxides (Figure 4), as observed. Apart from this, it is possible that the morphology of the particles and the energy of the band gap might also facilitate the photogeneration of $e_{C B}^{-} / h_{V B}^{+}$pairs to contribute to the photodegradation of phenol in this system.

Variations in photocatalytic efficiency amongst those catalysts that have been prepared by these authors and the $\mathrm{CdO} / \mathrm{ZnO} / \mathrm{Yb}_{2} \mathrm{O}_{3} \mathrm{NSs}$ synthesized from our investigations could be explained by the diverse patterns and electronic characteristics of the prototypes, which reflect variations in the terms of synthesis.

Considering the previous references, and on the basis of the assessed adsorption capabilities (Figure $4 \mathrm{a}$ ), the potential indirect mechanisms of photodegradation of phenol 
can be interpreted with regard to the photocatalytic performances of the two substances produced in this work.

The mechanism, as investigated by Honorio et al. [49] and Ong et al. [50], is related to the interaction of the reactions described in the equations below (Equations (10)-(20)). To summarize, it is possible that photogenerated electrons could react with $\mathrm{O}_{2}$ to generate the anionic radical $\mathrm{O}_{2}^{\bullet-}$ of superoxide and eventually the hydroxyl radical $\mathrm{OH}^{-}$. Alternatively, the photo-generated vacancies $h_{V B}^{+}$would interact with water in the medium to produce the hydroxyl radical $\mathrm{OH}$. An attack of the produced hydroxyl radicals on the dye molecules that adsorbed on the photocatalyst surface leads to the rapid generation of intermediate chemical compounds, and consequently to environmentally palatable green chemicals, namely $\mathrm{H}_{2} \mathrm{O}$ and $\mathrm{CO}_{2}$ (Equations (19) and (20)):

$$
\begin{aligned}
& \mathrm{CdO} / \mathrm{ZnO} / \mathrm{Yb}_{2} \mathrm{O}_{3} \stackrel{h v}{\rightarrow} \mathrm{CdO} / \mathrm{ZnO} / \mathrm{Yb}_{2} \mathrm{O}_{3}\left(e_{\mathrm{CB}}^{-}\right)+\left(h_{V B}^{+}\right) \\
& \mathrm{CdO} / \mathrm{ZnO} / \mathrm{Yb}_{2} \mathrm{O}_{3}\left(h_{V B}^{+}\right)+\mathrm{H}_{2} \mathrm{O} \rightarrow \mathrm{CdO} / \mathrm{ZnO} / \mathrm{Yb}_{2} \mathrm{O}_{3}+\mathrm{H}^{+}+\mathrm{OH}^{\bullet} \\
& \mathrm{CdO} / \mathrm{ZnO} / \mathrm{Yb}_{2} \mathrm{O}_{3}\left(h_{V B}^{+}\right)+\mathrm{OH}^{-} \rightarrow \mathrm{CdO} / \mathrm{ZnO} / \mathrm{Yb}_{2} \mathrm{O}_{3}+\mathrm{OH}^{\bullet} \\
& \mathrm{CdO} / \mathrm{ZnO} / \mathrm{Yb}_{2} \mathrm{O}_{3}\left(e_{\mathrm{CB}}^{-}\right)+\mathrm{O}_{2} \rightarrow \mathrm{CdO} / \mathrm{ZnO} / \mathrm{Yb}_{2} \mathrm{O}_{3}+\mathrm{O}_{2}^{\bullet-} \\
& \mathrm{O}_{2}^{\bullet-}+\mathrm{H}^{+} \rightarrow \mathrm{HO}_{2}^{\bullet} \\
& \mathrm{HO}_{2}^{\bullet}+\mathrm{HO}_{2}^{\bullet} \rightarrow \mathrm{H}_{2} \mathrm{O}_{2}+\mathrm{O}_{2} \\
& \mathrm{CdO} / \mathrm{ZnO} / \mathrm{Yb}_{2} \mathrm{O}_{3}\left(e_{\mathrm{CB}}^{-}\right)+\mathrm{H}_{2} \mathrm{O}_{2} \rightarrow \mathrm{OH}^{\bullet}+\mathrm{OH}^{-} \\
& \mathrm{H}_{2} \mathrm{O}_{2}+\mathrm{O}_{2}^{-} \rightarrow \mathrm{OH}^{\bullet}+\mathrm{OH}^{-}+\mathrm{O}_{2} \\
& \mathrm{H}_{2} \mathrm{O}_{2}+h v \rightarrow 2 \mathrm{OH}^{\circ}
\end{aligned}
$$

Organic compounds $+\mathrm{OH}^{\cdot} \rightarrow$ Intermediaries

$$
\text { Intermediaries } \rightarrow \mathrm{CO}_{2}+\mathrm{H}_{2} \mathrm{O}
$$

\subsubsection{Enhanced Photocatalytic Activity}

Xiao et al. [51] and Miklos et al. [52] have implemented the integration of hydrogen peroxide $\left(\mathrm{H}_{2} \mathrm{O}_{2}\right)$ and ultraviolet (UV) radiation to oxidize many biological contaminants, because $\mathrm{H}_{2} \mathrm{O}_{2}$ allows for improved generation of hydroxyl radicals $\left(\mathrm{OH}^{*}\right)$ to facilitate photodegradation. Nevertheless, the kinetics of the creation of these radicals is limited by an exclusive use of $\mathrm{H}_{2} \mathrm{O}_{2}$ and $\mathrm{UV}$ radiation. For this reason, to increase the photocatalyst production of hydroxyl radicals $\left(\mathrm{OH}^{-}\right)$and the photodegradation of phenol, the photoFenton method was implemented.

To prove that hydroxyl radicals are the major reactive species, a photocatalytic test in the presence of isopropyl alcohol should be carried out. Following photocatalysis in the presence of $\mathrm{H}_{2} \mathrm{O}_{2}$ and isopropyl, the UV-vis spectrum of phenol is shown in Figure 4c. Photo degradation results in view of the existence of $\mathrm{H}_{2} \mathrm{O}_{2}$ and isopropyl are illustrated in Figure $4 \mathrm{~d}$. It is observable that a satisfactory improvement in the percentage degradation was recorded after $15 \mathrm{~min}$ of photocatalysis involving the catalyst/ $\mathrm{H}_{2} \mathrm{O}_{2}$ /isopropyl/UVVis, in contrast to the experiments carried out in the lack of $\mathrm{H}_{2} \mathrm{O}_{2}$ (Figure $4 \mathrm{~b}$ ). It could also be noted that a relatively low rate of degradation for phenol was realized without a photocatalyst $\left(\mathrm{H}_{2} \mathrm{O}_{2}\right.$ /visible light) (Figure $\left.4 \mathrm{~b}\right)$. The outcome could be related to the low quantities of hydroxyl radicals $\left(\mathrm{OH}^{*}\right)$ generated in the procedure, suggesting a restriction of the activity of hydrogen peroxide in the Fenton approach.

In the case of the $\mathrm{CdO} / \mathrm{ZnO} / \mathrm{Yb}_{2} \mathrm{O}_{3} \mathrm{NSs}$, greater efficiencies were obtained after about 15 min, attaining a photodegradation rate of $97.81 \%$ of phenol (Figure $4 \mathrm{~d}$ ). With of $\mathrm{H}_{2} \mathrm{O}_{2}$ present, $\mathrm{CdO} / \mathrm{ZnO} / \mathrm{Yb}_{2} \mathrm{O}_{3} \mathrm{NSs}$ gained a much higher catalytic efficiency than that 
observed in the lack of $\mathrm{H}_{2} \mathrm{O}_{2}$ (Figure 4 d). Improved hydroxyl radical $\left(\mathrm{OH}^{-}\right)$production from the breakdown of the $\mathrm{Cd}^{2+}, \mathrm{Zn}^{2+}$, and $\mathrm{Yb}^{3}$ cations facilitated by $\mathrm{H}_{2} \mathrm{O}_{2}$ is attributable to this result, which is reproduced by the interaction between the cation and the photogenerated electrons $e_{C B}^{-}$and by the reaction of the vacancies $h_{V B}^{+}$with the water molecules present on the catalyst surface. It has been reported in the literature that hydrogen peroxide could also be catalyzed by $\mathrm{Cd}^{2+}$, ions; however, because of the low reaction of $\mathrm{Cd}$ (III) relative to $\mathrm{H}_{2} \mathrm{O}_{2}$, the decomposition of organic contaminants with photon Fenton reagents $\left(\mathrm{Cd}^{3+} / \mathrm{H}_{2} \mathrm{O}_{2}\right)$ is considerably slower than that with $\mathrm{Cd}^{2+} / \mathrm{H}_{2} \mathrm{O}_{2}$ reagents [52].

According to the above, the application of $\mathrm{H}_{2} \mathrm{O}_{2}$ is a key factor in enhancing the rate of photogenerated hydroxyl radicals $\left(\mathrm{OH}^{\bullet}\right)$ and consequently the photodegradation of organic dyes. As a result, we demonstrate that the reorganization of electron-hole pairs in this study is significantly inhibited and the phenol/catalyst $/ \mathrm{H}_{2} \mathrm{O}_{2}$ /isopropyl/UVvisible light irradiation (Figure 4c) generates more oxidation radicals $\left(\mathrm{OH}^{\bullet}\right)$ compared to the normal photocatalytic phenol/catalyst/UV-visible light (Figure 4b). In addition, all the above-mentioned results together indicate that the photocatalytic performance of the synthesized oxide materials is significantly improved.

\section{Conclusions}

The simple, well-controlled, one-pot hydrothermal approach was adopted for the effective synthesis of $\mathrm{CdO} / \mathrm{ZnO} / \mathrm{Yb}_{2} \mathrm{O}_{3}$ catalyst at elevated temperatures. After calcination at $600{ }^{\circ} \mathrm{C}$, well-crystallized $\mathrm{CdO} / \mathrm{ZnO} / \mathrm{Yb}_{2} \mathrm{O}_{3}$ was produced, which is described by $\mathrm{XRD}$, XPS, FTIR, SEM, and EDS. With $\mathrm{H}_{2} \mathrm{O}_{2}$ present, $\mathrm{CdO} / \mathrm{ZnO} / \mathrm{Yb}_{2} \mathrm{O}_{3}$ showed a higher catalytic activity $(97.81 \%)$ for phenol photodegradation. There is a considerable relationship between the effectiveness of the photocatalytic process and an indirect mechanism of heterogeneous photocatalysis. Our results demonstrate that light-driven photo-catalysis with the use of $\mathrm{CdO} / \mathrm{ZnO} / \mathrm{Yb}_{2} \mathrm{O}_{3}$ as catalyst may be regarded as more advantageous because of its financial feasibility and environmental durability, as solar light could be easily employed for such a process. Furthermore, the photocatalytic procedure could also facilitate the total decomposition of the organic pollutants (the mineralization of such chemical compounds in an environmentally acceptable manner, $\mathrm{CO}_{2}$ and $\mathrm{H}_{2} \mathrm{O}$ ) and reduce their toxicities. The synthesized composite is therefore a prospective candidate for the quick disposal of wastewater pollution with persistent organic pollutants.

Author Contributions: Conceptualization: W.J.; methodology: Z.L.; validation: H.Z.; formal analysis: Z.L., H.Z. and W.J.; data curation: Z.L.; writing-original draft: Z.L.; writing-review and editing: Z.L. All authors have read and agreed to the published version of the manuscript.

Funding: This research was funded by the Nature Science Foundation of Heilongjiang province of China, grant number LH2019E113, and the Youth Doctor Foundation of Harbin university, grant number HUDF2017105.

Data Availability Statement: The data presented in this study are available on request from the corresponding author.

Acknowledgments: The authors acknowledge the School of Food Engineering of Harbin University and Harbin Institute of Technology. Z.L. would like to thank to the Youth Doctor Foundation of Harbin University (grant HUDF2017105). H.K.Z. would like to thank the NSF (grant LH2019E113).

Conflicts of Interest: The authors declare no conflict of interest.

\section{References}

1. Molinari, C.; Conte, S.; Zanelli, C.; Ardit, M.; Cruciani, G.; Dondi, M. Ceramic pigments and dyes beyond the inkjet revolution: From technological requirements to constraints in colorant design. Ceram. Int. 2020, 46, 21839-21872. [CrossRef]

2. Wei, F.; Shahid, M.; Alnusairi, G.; Afzal, M.; Khan, A.; El-Esawi, M.; Abbas, Z.; Wei, K.; Zaheer, I.; Rizwan, M.; et al. Implementation of Floating Treatment Wetlands for Textile Wastewater Management: A Review. Sustainability 2020, $12,5801$. [CrossRef]

3. Wang, Z.; Wang, X.; Cong, S.; Geng, F.; Zhao, Z. Fusing electrochromic technology with other advanced technologies: A new roadmap for future development. Mater. Sci. Eng. R Rep. 2020, 140, 100524. [CrossRef] 
4. Ardakani, M.N.; Gholikandi, G.B. Microbial fuel cells (MFCs) in integration with anaerobic treatment processes (AnTPs) and membrane bioreactors (MBRs) for simultaneous efficient wastewater/sludge treatment and energy recovery-A state-of-the-art review. Biomass Bioenergy 2020, 141, 105726. [CrossRef]

5. Liu, L.; Cheng, Q. Mass transfer characteristic research on electrodialysis for desalination and regeneration of solution: A comprehensive review. Renew. Sustain. Energy Rev. 2020, 134, 110115. [CrossRef]

6. Rahmat, M.; Rehman, A. Highly efficient removal of crystal violet dye from water by $\mathrm{MnO}_{2}$ based nanofibrous mesh/photocatalytic process. J. Mater. Res. Technol. 2019, 8, 5149-5159. [CrossRef]

7. Luo, T.; Wang, H.; Chen, L.; Li, J.; Wu, F.; Zhou, D. Visible light-driven oxidation of arsenite, sulfite and thiazine dyes: A new strategy for using waste to treat waste. J. Clean. Prod. 2021, 280, 124374. [CrossRef]

8. Negishi, N.; Miyazaki, Y. Effect of $\mathrm{HCO}_{3}$ - concentration in groundwater on $\mathrm{TiO}_{2}$ photocatalytic water purifica-tion. Appl. Catal. B-Environ. 2019, 242, 449-459. [CrossRef]

9. Suthakaran, S.; Dhanapandian, S.; Krishnakumar, N.; Ponpandian, N. Surfactants assisted $\mathrm{SnO}_{2}$ nanoparticles synthesized by a hydrothermal approach and potential applications in water purification and energy conversion. J. Mater. Sci. Mater. Electron. 2019, 30, 13174-13190. [CrossRef]

10. Youssef, Z.; Colombeau, L.; Yesmurzayeva, N.; Baros, F.; Vanderesse, R.; Hamieh, T.; Toufaily, J.; Frochot, C.; Roques-Carmes, T.; Acherar, S. Dye-sensitized nanoparticles for heterogeneous photocatalysis: Cases studies with $\mathrm{TiO}_{2}, \mathrm{ZnO}$, fullerene and graphene for water purification. Dye. Pigment. 2018, 159, 49-71. [CrossRef]

11. Chaudharyab, K.; Shaheena, N.; Zulfiqarc, S.; Sarwar, M.I.; Sulemane, M.; Agboola, P.O.; Shakirg, I.; Warsi, M.F. Binary WO 3 -ZnO nanostructures supported rGO ternary nanocomposite for visible light driven photocatalytic degradation of methylene blue. Synth. Met. 2020, 269, 116526. [CrossRef]

12. Trawiński, J.; Skibiński, R. Multivariate comparison of photocatalytic properties of thirteen nanostructured metal oxides for water purification. J. Environ. Sci. Health Part A 2019, 54, 851-864. [CrossRef] [PubMed]

13. Tayebee, R.; Esmaeili, E.; Maleki, B.; Khoshniat, A.; Chahkandi, M.; Mollania, N. Photodegradation of methylene blue and some emerging pharmaceutical micropollutants with an aqueous suspension of $\mathrm{WZnO}-\mathrm{NH}_{2} @ \mathrm{H}_{3} \mathrm{PW}_{12} \mathrm{O}_{40}$ nanocomposite. J. Mol. Liq. 2020, 317, 113928. [CrossRef]

14. Karthikeyan, C.; Arunachalam, P.; Ramachandran, K.; Al-Mayouf, A.M.; Karuppuchamy, S. Recent advances in semiconductor metal oxides with enhanced methods for solar photocatalytic applications. J. Alloy. Compd. 2020, 828, 154281. [CrossRef]

15. Wu, Y.; Wang, H.; Tu, W.; Wu, S.; Liu, Y.; Tan, Y.Z.; Luo, H.; Yuan, X.; Chew, J.W. Petal-like CdS nanostructures coated with exfoliated sulfur-doped carbon nitride via chemically activated chain termination for enhanced visible-light-driven photocatalytic water purification and $\mathrm{H}_{2}$ generation. Appl. Catal. B Environ. 2018, 229, 181-191. [CrossRef]

16. Sabet, M.; Mohammadi, M.; Googhari, F. Prominent Visible Light Photocatalytic and Water Purification Activity of PbS/CdS/CdO Nanocomposite Synthesized via Simple Co-Precipitation Method. Nanosci. Nanotechnol. Asia 2019, 9, 278-284. [CrossRef]

17. Wang, X.; Brigante, M.; Dong, W.; Wu, Z.; Mailhot, G. Degradation of Acetaminophen via UVA-induced advanced oxidation processes (AOPs). Involvement of different radical species: $\mathrm{HO}, \mathrm{SO}_{4}{ }^{-}$and $\mathrm{HO}_{2} \cdot \mathrm{O}_{2}{ }^{--}$. Chemosphere 2020, 258, 127268. [CrossRef] [PubMed]

18. Ramesh, R.K.; Chottanahalli, S.P.K.; Madegowda, N.M.; Rai, V.R.; Ananda, S. Electrochemical synthesis of hierarchal flower-like hierarchical $\mathrm{In}_{2} \mathrm{O}_{3} / \mathrm{ZnO}$ nanocatalyst for textile industry effluent treatment, photo-voltaic, $\mathrm{OH}$ scavenging and anti-bacterial studies. Catal. Commun. 2017, 89, 25-28. [CrossRef]

19. Kumar, M.R.; Murugadoss, G.; Pirogov, A.N.; Thangamuthu, R. A facile one step synthesis of $\mathrm{SnO}_{2} / \mathrm{CuO} \mathrm{and} \mathrm{CuO} / \mathrm{SnO}_{2}$ nanocomposites: Photocatalytic application. J. Mater. Sci. Mater. Electron. 2018, 29, 13508-13515. [CrossRef]

20. Zeleke, M.A.; Kuo, D.-H.; Ahmed, K.E.; Gultom, N.S. Facile synthesis of bimetallic $(\mathrm{In}, \mathrm{Ga})_{2}(\mathrm{O}, \mathrm{S})_{3}$ oxy-sulfide nanoflower and its enhanced photocatalytic activity for reduction of Cr(VI). J. Colloid Interface Sci. 2018, 530, 567-578. [CrossRef] [PubMed]

21. Sudrajat, H.; Hartuti, S.; Babel, S.; Nguyen, T.K.; Tong, H.D. $\mathrm{SnO}_{2} / \mathrm{ZnO}$ heterostructured nanorods: Structural properties and mechanistic insights into the enhanced photocatalytic activity. J. Phys. Chem. Solids 2021, 149, 109762. [CrossRef]

22. Yu, Y.; Yang, Q.; Ma, J.; Sun, W.; Yin, C.; Li, X.; Guo, J.; Jiang, Q.; Lu, Z. Construction of Strontium Titanate/Binary Metal Sulfide Heterojunction Photocatalysts for Enhanced Visible-Light-Driven Photocatalytic Activity. Nano 2018, 13, 11. [CrossRef]

23. Sales, H.; Menezes, R.; Neves, G.; Souza, J.; Ferreira, J.; Chantelle, L.; De Oliveira, A.M.; Lira, H. Development of Sustainable Heterogeneous Catalysts for the Photocatalytic Treatment of Effluents. Sustainability 2020, 12, 7393. [CrossRef]

24. Adnan, M.A.M.; Julkapli, N.M.; Hamid, S.B.A. Review on ZnO hybrid photocatalyst: Impact on photocatalytic activities of water pollutant degradation. Rev. Inorg. Chem. 2016, 36, 77-104. [CrossRef]

25. Kumar, S.; Gupta, M.; Sathe, V.; Shripathi, T.; Phase, D.; Das, B. Study of the structural phase transformation, and optical behavior of the as synthesized $\mathrm{ZnO}-\mathrm{SnO}_{2}-\mathrm{TiO}_{2}$ nanocomposite. Phase Transit. 2015, 88, 1122-1136. [CrossRef]

26. Kumar, D.P.; Park, H.; Kim, E.H.; Hong, S.; Gopannagari, M.; Reddy, D.A.; Kim, T.K. Noble metal-free metal-organic frameworkderived onion slice-type hollow cobalt sulfide nanostructures: Enhanced activity of CdS for improving photocatalytic hydrogen production. Appl. Catal. B Environ. 2018, 224, 230-238. [CrossRef]

27. Vaizoğullar, A.I. Ternary CdS/ $\mathrm{MoS}_{2} / \mathrm{ZnO}$ Photocatalyst: Synthesis, Characterization and Degradation of Ofloxacin under Visible Light Irradiation. J. Inorg. Organomet. Polym. Mater. 2020, 30, 4129-4141. [CrossRef]

28. Ma, W.; Mack, D.; Malzbender, J.; Vaßen, R.; Stöver, D. $\mathrm{Yb}_{2} \mathrm{O}_{3}$ and $\mathrm{Gd}_{2} \mathrm{O}_{3}$ doped strontium zirconate for thermal barrier coatings. J. Eur. Ceram. Soc. 2008, 28, 3071-3081. [CrossRef] 
29. Liu, T.; Bai, X.; Miao, C.; Dai, Q.; Xu, W.; Yu, Y.; Chen, Q.; Song, H. Yb ${ }_{2} \mathrm{O}_{3} /$ Au Upconversion Nanocomposites with Broad-Band Excitation for Solar Cells. J. Phys. Chem. C 2014, 118, 3258-3265. [CrossRef]

30. Chiappetta, G.; Ndiaye, S.; Igbaria, A.; Kumar, C.; Vinh, J.; Toledano, M.B. Proteome Screens for Cys Residues Oxidation. Methods Enzymol. 2010, 473, 199-216. [CrossRef] [PubMed]

31. Rahman, M.M.; Alam, M.M.; Asiri, A.M.; Islam, M.A. Ethanol sensor development based on ternary-doped metal oxides $\left(\mathrm{CdO} / \mathrm{ZnO} / \mathrm{Yb}_{2} \mathrm{O}_{3}\right)$ nanosheets for environmental safety. RSC Adv. 2017, 7, 22627-22639. [CrossRef]

32. Sales, H.B.; Bouquet, V.; Députier, S.; Ollivier, S.; Gouttefangeas, F.; Guilloux-Viry, M.; Dorcet, V.; Weber, I.T.; De Souza, A.G.; Dos Santos, I.M.G. $\mathrm{Sr}_{1-\mathrm{x}} \mathrm{Ba}_{\mathrm{x}} \mathrm{SnO}_{3}$ system applied in the photocatalytic discoloration of an azo-dye. Solid State Sci. 2014, 28, 67-73. [CrossRef]

33. Rahman, Q.I.; Ahmad, M.; Misra, S.K.; Lohani, M. Effective photocatalytic degradation of rhodamine B dye by ZnO nanoparticles. Mater. Lett. 2013, 91, 170-174. [CrossRef]

34. Chantelle, L.; De Oliveira, A.L.M.; Kennedy, B.J.; Maul, J.; Da Silva, M.R.S.; Duarte, T.M.; Albuquerque, A.R.; Sambrano, J.R.; Landers, R.; Siu-Li, M.; et al. Probing the Site-Selective Doping in $\mathrm{SrSnO}_{3}: E u$ Oxides and Its Impact on the Crystal and Electronic Structures Using Synchrotron Radiation and DFT Simulations. Inorg. Chem. 2020, 59, 7666-7680. [CrossRef]

35. Soylu, M.; Kader, H.S. Photodiode Based on CdO Thin Films as Electron Transport Layer. J. Electron. Mater. 2016, 45, 5756-5763. [CrossRef]

36. Thema, F.; Beukes, P.; Gurib-Fakim, A.; Maaza, M. Green synthesis of Monteponite CdO nanoparticles by Agathosma betulina natural extract. J. Alloy. Compd. 2015, 646, 1043-1048. [CrossRef]

37. Gutul, T.; Rusu, E.; Condur, N.; Ursaki, V.; Goncearenco, E.; Vlazan, P. Preparation of poly(N-vinylpyrrolidone)-stabilized ZnO colloid nanoparticles. Beilstein J. Nanotechnol. 2014, 5, 402-406. [CrossRef] [PubMed]

38. Wang, Y.; Chen, M.; Li, Y.; Du, Q.; Yuan, Y.; Ren, Y.; Liu, B.; Zhao, H.; Yang, H. Enhancing gas sensitivity of CdO octahedrons having $\{111\}$ facets by hydrogenation and sensing mechanism of 3-coordinated Cd atoms as the reactive centers. Appl. Surf. Sci. 2020, 506, 144868. [CrossRef]

39. Qian, C.; Zeng, T.; Liu, H. Synthesis and Downconversion Emission Property of $\mathrm{Yb}_{2} \mathrm{O}_{3}: \mathrm{Eu}^{3+}$ Nanosheets and Nanotubes. Adv. Condens. Matter Phys. 2013, 2013, 1-5. [CrossRef]

40. Shestakov, M.V.; Tikhomirov, V.K.; Kirilenko, D.; Kuznetsov, A.S.; Chibotaru, L.F.; Baranov, A.N.; Van Tendeloo, G.; Moshchalkov, V.V. Quantum cutting in $\mathrm{Li}(770 \mathrm{~nm})$ and $\mathrm{Yb}(1000 \mathrm{~nm})$ co-dopant emission bands by energy transfer from the ZnO nano-crystalline host. Opt. Express 2011, 19, 15955-15964. [CrossRef] [PubMed]

41. Bagal, V.S.; Patil, G.P.; Deore, A.B.; Suryawanshi, S.R.; Late, D.J.; More, M.A.; Chavan, P.G. Surface modification of aligned CdO nanosheets and their enhanced field emission properties. RSC Adv. 2016, 6, 41261-41267. [CrossRef]

42. Haeberle, J.; Henkel, K.; Gargouri, H.; Naumann, F.; Gruska, B.; Arens, M.; Tallarida, M.; Schmeißer, D. Ellipsometry and XPS comparative studies of thermal and plasma enhanced atomic layer deposited $\mathrm{Al}_{2} \mathrm{O}_{3}$-films. Beilstein J. Nanotechnol. 2013, 4, 732-742. [CrossRef] [PubMed]

43. Lee, H.L.; Mohammed, I.A.; Belmahi, M.; Assouar, M.B.; Rinnert, H.; Alnot, M. Thermal and Optical Properties of CdS Nanoparticles in Thermotropic Liquid Crystal Monomers. Materials 2010, 3, 2069-2086. [CrossRef]

44. Xu, D.; Fan, D.; Shen, W. Catalyst-free direct vapor-phase growth of $\mathrm{Zn}_{1-\mathrm{x}} \mathrm{Cu}_{\mathrm{x}} \mathrm{O}$ micro-cross structures and their optical properties. Nanoscale Res. Lett. 2013, 8, 46. [CrossRef]

45. Zhang, F.; Wu, X.; Liang, C.; Li, X.; Wang, Z.; Li, H. Highly active, water-compatible and easily separable magnetic mesoporous Lewis acid catalyst for the Mukaiyama-Aldol reaction in water. Green Chem. 2014, 16, 3768-3777. [CrossRef]

46. Yin, Q.; Jin, X.; Yang, G.; Jiang, C.; Song, Z.; Sun, G. Biocompatible folate-modified $\mathrm{Gd}^{3+} / \mathrm{Yb}^{3+}$-doped ZnO nanoparticles for dualmodal MRI/CT imaging. RSC Adv. 2014, 4, 53561-53569. [CrossRef]

47. Duarte, A.A.L.S.; Cardoso, S.J.A.; Alçada, A.J. Emerging and Innovative Techniques for Arsenic Removal Applied to a Small Water Supply System. Sustainability 2009, 1, 1288-1304. [CrossRef]

48. Molinari, R.; Argurio, P.; Poerio, T. Membrane Processes Based on Complexation Reactions of Pollutants as Sustainable Wastewater Treatments. Sustainability 2009, 1, 978-993. [CrossRef]

49. Honorio, L.M.C.; de Oliveira, A.L.M.; Filho, E.C.D.S.; Osajima, J.A.; Hakki, A.; Macphee, D.E.; dos Santos, I.M.G. Supporting the photocatalysts on $\mathrm{ZrO}_{2}$ : An effective way to enhance the photocatalytic activity of $\mathrm{SrSnO}_{3}$. Appl. Surf. Sci. 2020, 528, 146991. [CrossRef]

50. Ong, C.B.; Ng, L.Y.; Mohammad, A.W. A review of $\mathrm{ZnO}$ nanoparticles as solar photocatalysts: Synthesis, mechanisms and applications. Renew. Sustain. Energy Rev. 2018, 81, 536-551. [CrossRef]

51. Xiao, C.; Li, J.; Zhang, G. Synthesis of stable burger-like $\alpha-\mathrm{Fe}_{2} \mathrm{O}_{3}$ catalysts: Formation mechanism and excellent photo-Fenton catalytic performance. J. Clean. Prod. 2018, 180, 550-559. [CrossRef]

52. Miklos, D.B.; Remy, C.; Jekel, M.; Linden, K.G.; Drewes, J.E.; Hübner, U. Evaluation of advanced oxidation processes for water and wastewater treatment-A critical review. Water Res. 2018, 139, 118-131. [CrossRef] [PubMed] 